\title{
PENINGKATAN HASIL BELAJAR OPERASI ALJABAR MELALUI STRATEGI PEER LESSON DENGAN MEDIA KARTU SISWA SMP
}

\author{
Nuralam $^{1}$, Evi Juslinda ${ }^{1}$ \\ ${ }^{1}$ Universitas Islam Negeri Ar-Raniry, Jalan Syeikh Abdur Rauf, Banda Aceh 23111, Indonesia \\ Email: nuralam@ar-raniry.ac.id \\ Email: evi.juslinda080193@ gmail.com
}

\begin{abstract}
Abstrak
Pembelajaran matematika memerlukan strategi dan media belajar yang tepat yang salah satunya strategi peer lesson dengan media kartu agar hasil belajar matematika siswa menjadi optimal. Tujuan penelitian ini mendeskripsikan strategi peer lesson dengan media kartu yang dapat meningkatkan hasil belajar operasi aljabar. Rancangan penelitian ini adalah penelitian tindakan kelas melalui empat tahap yaitu tahap perencanaan, pelaksanaan, observasi dan refleksi. Subjek penelitian sebanyak 32 siswa dari kelas VIII SMPN 1 Aceh Besar. Instrumen penelitian menggunakan lembar observasi dan tes hasil belajar. Analisis data menggunakan analisis statistik deskriptif. Hasil penelitian menunjukkan bahwa ada peningkatan aktivitas guru dan aktivitas siswa melalui strategi peer lesson dengan media kartu. Hasil belajar operasi aljabar meningkat dari siklus I ke siklus II sebesar $12 \%$ dan rerata tes akhir sebesar 93,75\%. Disimpulkan bahwa strategi peer lesson dengan media kartu dapat meningkatkan aktivitas guru dan siswa serta hasil belajar operasi aljabar.
\end{abstract}

Kata kunci: Hasil Belajar Matematika, Operasi Aljabar, Strategi Peer Lesson, Media Kartu

\begin{abstract}
Mathematics learning requires the right strategy and learning media, one of which is the peer lesson strategy with card media so that students' mathematics learning outcomes become optimal. The purpose of this study is to describe the peer lesson strategy with card media that can improve the learning outcomes of algebraic operations. The design of this study is classroom action research through four stages, namely the stages of planning, implementation, observation and reflection. The subjects of the study were 32 students from class VIII of SMPN 1 Aceh Besar. The research instrument used observation sheets and test results. Data analysis using descriptive statistical analysis. The results showed that there was an increase in teacher activity and student activities through peer lesson strategies with card media. The learning outcomes of algebraic operations increased from cycle I to cycle II by $12 \%$ and the average final test was $93.75 \%$. It was concluded that the peer lesson strategy with card media could increase the activity of teachers and students as well as the results of learning algebraic operations.
\end{abstract}

Key words: Mathematics Learning Outcomes, Algebraic Operations, Peer Lesson Strategies, Card Media

\section{PENDAHULUAN}

Inovasi dalam pendidikan yang secara terukur dan sistematis menjadi salah satu cara agar mutu sumber daya manusia Indonesia tidak gagap dalam menghadapi tantangan masa depan. Tantangan masa depan tersebut, tidak terlepas dari perkembangan ilmu pengetahuan dan teknologi. Inovasi tersebut dilakukan pemerintah termasuk salah satunya dalam penguatan pendidikan matematika di sekolah, antara lain melalui program studi lanjut yang relevan, pelatihan dan penataran yang berdaya guna dan berhasil guna, penyempurnaan kurikulum dan pengadaan fasiltas belajar yang lebih memadai. Peningkatan kapasitas kualitas akan menciptakan manusia Indonesia yang unggul sehingga dapat menghadapi dan menjawab persoalan di masa depan. 
Penguatan pendidikan di bidang matematika yang merupakan salah satu pengetahuan dasar turut memberikan kontribusi bagi kemajuan dalam berbagai bidang. Menurut Susilo (2012) bahwa penguatan dasar matematika memberikan kontribusi pada kemampuan berpikir dan bernalar dengan benar agar dapat digunakan untuk menyelesaikan masalah dalam kehidupan sehari-hari. Oleh karena itu, matematika sudah diajarkan sejak dari sekolah dasar sampai ke perguruan tinggi. Tujuan matematika diajarkan di sekolah menengah pertama agar siswa memiliki kemampuan memahami konsep matematika, menggunakan penalaran, memecahkan masalah, mengkomunikasikan gagasan dan memiliki sikap menghargai kegunaan matematika dalam kehidupan nyata. Mengingat begitu penting peranan matematika sudah sepatutnya diberikan perhatian lebih terhadap pembelajaran matematika untuk setiap jenjang pendidikan.

Untuk mewujudkan tujuan pembelajaran matematika khususnya di jenjang SMP, guru memiliki peran yang sangat penting dalam menentukan kualitas pembelajaran di dalam kelas. Guru harus mampu mendesain pembelajaran yang sistematis, kreatif, dan aktif dalam ruang belajarnya (Suherman, 2001). Guru adalah pihak yang paling berperan dan bertanggung jawab dalam memfasilitasi siswa agar dapat belajar dengan optimal di kelas. Sebagai fasilitator, guru berperan memberikan pelayanan untuk memudahkan siswa dalam kegiatan proses pembelajaran yang efektif dan efesien (Sanjaya, 2007). Proses pembelajaran yang efektif dan efesien akan tercipta, jika peran guru sebagai fasilitator dalam proses kegiatan tersebut dapat diterapkan secara maksimal. Di samping itu, guru juga berfungsi sebagai pencipta kondisi yang kondusif selama berlangsungnya kegiatan belajar mengajar. Kondisi ini diciptakan untuk membantu perkembangan siswa secara optimal. Upaya yang dilakukan guru hendaknya mampu membangkitkan semangat siswa dalam berpikir sehingga hasil belajarnya optimal.

Ada beberapa alasan tentang perlunya siswa belajar matematika. Menurut Cockroft dalam Abdurrahman (2012) bahwa matematika itu: (1) selalu digunakan dalam kehidupan, (2) semua bidang ilmu memerlukan keterampilan matematika, (3) sarana komunikasi yang singkat, jelas dan kuat, (4) menyajikan informasi berbagai cara, (5) meningkatkan kemampuan berpikir logis, teliti, kesadaran atas keruangan, (6) memberi kepuasan atas usaha memecahkan masalah yang menantang. Jika dicermati lebih lanjut bahwa matematika perlu dibelajarkan kepada siswa agar dapat mempergunakannya dalam menyelesaikan masalah dalam kehidupan nyata. Belajar matematika itu memiliki relasi dengan perolehan hasil belajarnya. Karena keberadaan siswa dalam mempelajari matematika dapat dicermati dari perolehan hasil belajar matematikanya (Nuralam dan Gadeng, 2018).

Menurut Sunarto dan Hartono (2006) bahwa hasil belajar merupakan kemampuan kognitif paduan dari faktor bawaan dan faktor lingkungan. Hasil belajar sebagai kemampuan yang dimiliki siswa setelah menerima pengalaman kerjanya (Sudjana, 2011). Dapat pula dikatakan sebagai perubahan perilaku seseorang yang berdasarkan variabel bawaannya melalui perlakuan pembelajaran tertentu (Gagne, 1983). Perubahan perilaku belajar tersebut dapat dicermati dari aspek pengetahuan, sikap dan keterampilan. Ketiga aspek itu digunakan sebagai bahan evaluasi pembelajaran matematika selanjutnya. Jadi guru diharapkan mampu menyusun, mengelola, dan membimbing kegiatan siswa lebih lanjut dalam pembelajaran matematika selanjutnya.

Persoalan kerap terjadi dalam pembelajaran matematika, masih banyak peserta didik perolehan hasil belajar matematika yang kurang optimal. Ada asumsi menunjukkan bahwa selama ini pembelajaran matematika lebih berorientasi pada menghafal daripada pemahaman. Karena lebih banyak menghafal, maka berdampak dalam memahami mata pelajaran matematika (Ruseffendi, 2005). Berdasarkan observasi awal dan wawancara yang peneliti lakukan dengan guru bidang studi matematika di kelas VIII SMPN 1 Darussalam Aceh Besar, ditemukan permasalahan dalam pembelajaran matematika. Permasalahan tersebut antara lain: (1) siswa kurang terlibat dalam proses pembelajaran sehingga suasana kelas membosankan; (2) saat siswa diberi kesempatan untuk bertanya dan berpendapat, sebagian besar siswa hanya diam saja; (3) siswa menghindari kontak mata dengan 
guru dan menunggu guru menunjuk salah satu dari mereka untuk maju ke papan tulis; (4) ketika ditanya sudah paham siswa serentak menjawab sudah; dan 5) ketika diberikan tes atau ulangan matematika masih banyak siswa yang belum dapat menjawab dengan benar dan perolehan hasil belajar tidak mencapai kriteria ketuntasan minimalnya. Kondisi pembelajaran matematika yang demikian memerlukan perhatian dari para pendidik matematika agar dapat ditangani dengan sebaiknya. Untuk mengatasi keadaan tersebut, guru sebagai komponen utama dalam proses pembelajaran diharapkan mampu menerapkan strategi pembelajaran yang dapat meningkatkan partisipasi aktif siswa dalam belajar agar hasil belajarnya menjadi optimal. Oleh karena itu dalam proses pembelajaran, guru dituntut mampu memilih strategi pembelajaran yang selektif sesuai dengan kemampuan siswa. Salah satu strategi pembelajaran yang dapat dilakukan untuk mengaktifkan dan meningkatkan hasil belajar siswa adalah dengan menerapkan strategi peer lesson dengan media kartu.

Strategi peer lesson adalah suatu tipe dalam pembelajaran aktif yang menekankan siswa mengajar siswa lainnya yang mengalami kesulitan dalam memahami materi. Perlu diperhatikan bahwa siswa bukan hanya dijadikan sebagai objek pembelajaran tetapi menjadi subjek pembelajaran. Siswa diajak untuk menjadi sumber belajar dan tempat berbagi pengetahuan bagi temannya. Menurut Zaini (2008), strategi peer lesson baik digunakan untuk menggairahkan kemauan siswa untuk mengajarkan materi kepada temannya. Silberman (2009) menyatakan bahwa strategi peer lesson mengembangkan keinginan siswa mengajarkan materi dalam kelas yang menempatkan seluruh tanggung jawab untuk mengajar para peserta didik sebagai anggota kelas. Strategi ini memungkinkan untuk menumbuhkan sikap tanggung jawab, bekerja sama antara siswa, maupun bekerja aktif dan meningkatkan minat dalam belajar matematika. Strategi peer lesson memiliki langkah dan proses yang berbeda dengan strategi pembelajaran aktif lainnya, namun masih dalam tatanan pengorganisasian siswa ke dalam belajar aktif. Adapun langkah pembelajarannya disajikan pada Tabel 1 berikut ini.

Tabel 1. Langkah Strategi Peer Lesson

\begin{tabular}{lll}
\hline \multicolumn{1}{c}{ langkah } & \multicolumn{3}{c}{ Aktivitas } \\
\hline Pembagian kelas ke dalam sub kelompok & $\begin{array}{l}\text { Membuat sub kelompok sebanyak topik yang diajarkan } \\
\text { di kelas }\end{array}$ \\
\hline $\begin{array}{l}\text { Pembagian sub topik saling berhubungan } \\
\text { dari topik }\end{array}$ & $\begin{array}{l}\text { Memberikan masing-masing kelompok sejumlah } \\
\text { informasi, konsep, atau keahlian untuk mengajar yang } \\
\text { lain yang berhubungan antar topic }\end{array}$ \\
\hline Presentasi kelas setiap kelompok & $\begin{array}{l}\text { Setiap kelompok untuk membuat presentasi atau } \\
\text { mengajarkan topiknya kepada siswa di kelas }\end{array}$ \\
\hline Penyiapan media pembelajaran & $\begin{array}{l}\text { Melibatkan sesama peserta didik dalam proses } \\
\text { pembelajaran melalui media }\end{array}$ \\
\hline Komunikasikan materi di depan kelas & $\begin{array}{l}\text { Setiap kelompok menyampaikan materi sesuai tugas } \\
\text { yang telah diberikan }\end{array}$ \\
\hline Kesimpulan dan klarifikasi & $\begin{array}{l}\text { Memberikan kesimpulan dan klarifikasi dalam } \\
\text { mensinergiskan pemahaman siswa }\end{array}$ \\
\hline
\end{tabular}

Sumber: Adaptasi dari Zaini (2008).

Jika dicermati pada langkah strategi peer lesson pada Tabel 1 tersebut, ada langkah penyiapan media pembelajaran yang diharapkan melibatkan sesama siswa dalam belajar. Pemakaian media pembelajaran bagi siswa dapat membantu keefektifan proses pembelajaran dan penyampaian pesan, disamping membawa pengaruh psikologis siswa dalam belajar (Sari dan Faisal, 2018). Dalam penelitian ini menggunakan media kartu. Media kartu digunakan untuk memudahkan pemahaman siswa dalam belajar operasi aljabar. Agar siswa lebih memahami dan untuk menguasai konsep variabel dan bilangan pada materi tersebut maka dibuat media kartu berupa kartu variabel dan kartu bilangan. Dari beberapa hasil penelitian menunjukkan bahwa strategi peer lesson memberikan 
dampak positif bagi peningkatan hasil belajar siswa dan keaktifan belajarnya (Mulasiwi, Susilaningsih, \& Sumaryati, 2017; Relita, Marganingsih, \& Ningsih, 2017). Hal ini dapat dicermati dari hasil penelitian yang ditunjukkan dengan siswa belajar secara aktif dalam membangun pengetahuannya.

Berdasarkan uraian latar belakang masalah berkaitan dengan peningkatan hasil belajar melalui strategi peer lesson dengan media kartu, peneliti tertarik mengkaji lebih lanjut dalam suatu penelitian. Berdasarkan uraian tersebut, maka penelitian ini bertujuan untuk mendeskripsikan: aktivitas guru, aktivitas siswa, respon siswa dan peningkatan hasil belajar operasi aljabar melalui strategi peer lesson dengan media kartu. Adapun manfaat penelitian diharapkan sebagai tambahan wawasan dalam rangka meningkatkan hasil belajar matematika, dan sebagai riset yang berkelanjutan berkaitan dengan strategi peer lesson dengan media kartu.

\section{METODE PENELITIAN}

Penelitian ini menggunakan penelitian tindakan kelas kolaboratif (Arikunto, Suhardjono, \& Supardi, 2009). Artinya dilakukan bersama peneliti dan guru matematika sekolah, dengan dua siklus yang bertujuan untuk mendeskripsikan perkembangan perubahan perolehan hasil belajar matematika. Setiap siklus terdiri dari 4 tahap yaitu: perencanaan, pelaksanaan, pengamatan dan refleksi. Subjek yang diteliti adalah siswa kelas VIII ${ }_{1}$ SMPN 1 Darussalam Aceh Besar. Instrumen penelitian menggunakan lembar observasi, soal tes hasil belajar matematika dan lembar angket siswa. Data dikumpulkan menggunakan teknik tes, lembar observasi pembelajaran dan angket respon siswa. Adapun kriteria keberhasilan tindakan dicapai dalam penelitian ini yaitu: (1) aktivitas guru dalam mengelola pembelajaran dari setiap aspek dinilai berada pada kategori minimal baik, (2) aktivitas siswa dalam belajar aktif ditandai dengan keberanian bertanya dan berpartisipasi yang sesuai alokasi waktu pada rencana pelaksanaan pembelajaran, (3) respon siswa ditandai dari setiap aspek komponen pembelajaran dalam kategori minimal positif, dan (4) hasil belajar matematika meningkat pada tiap indikator maupun keseluruhan dari setiap siklus.

Adapun prosedur penelitian tindakan kelas melalui 4 tahap yang dilakukan untuk setiap siklus mengikuti tahapan-tahapan penelitian tindakan, yaitu: 1) perencanaan tindakan, 2) pelaksanaan tindakan, 3) melaksanakan observasi, dan 4) melakukan kegiatan refleksi (Arikunto, Suhardjono, \& Supardi, 2009). Tahapan tersebut seperti digambarkan berikut ini.

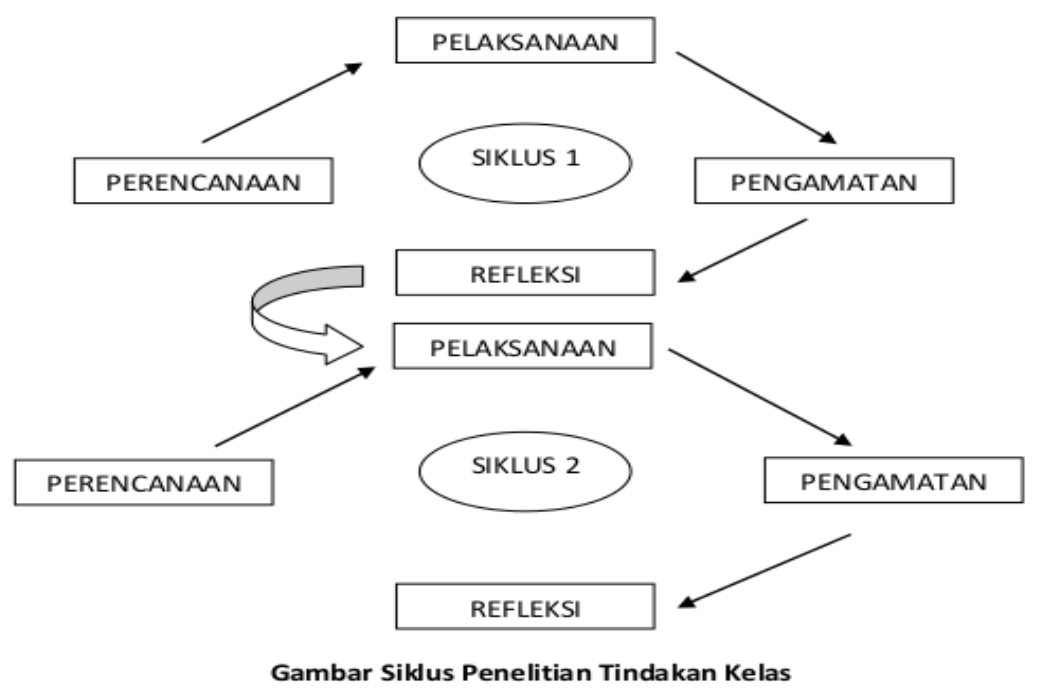


Pada tahap perencanaan tindakan siklus I, peneliti menyusun sebagai berikut: (1) RPP 1; (2) LKPD 1; (3) soal tes siklus 1; (4) lembar observasi aktivitas guru dan siswa; dan (5) angket respon siswa. Selanjutnya melakukan tindakan berupa kegiatan pembelajaran sesuai dengan RPP 1 yang telah dipersiapkan. Pada saat pelaksanaan tindakan, dilakukan pengamatan oleh 2 orang pengamat dari teman sejawat terhadap aktivitas guru dan siswa. Setelah selesai proses tersebut, maka peneliti bersama teman sejawat melakukan refleksi terhadap pelaksanaan RPP 1. Dari hasil refleksi tersebut dijadikan bahan pertimbangan dan acuan dalam menyempurnakan penyusunan RPP 2 pada kegiatan siklus II. Selanjutnya peneliti melakukan tindakan sesuai dengan RPP 2 dan melakukan kegiatan hal serupa pada siklus II. Setelah selesai dilaksanakan, maka selanjutnya adalah melakukan analisis terhadap setiap data yang diperoleh selama penelitian. Analisis data meliputi: (1) aktivitas guru; (2) aktivitas siswa; dan (3) hasil belajar siswa.

\section{HASIL PENELITIAN DAN PEMBAHASAN}

Penelitian dimulai kegiatan pra tindakan. Peneliti membuat pemetaan subjek, penyusunan jadwal, observasi kelas dan peneliti berkolaborasi dengan guru matematika berkaitan subjek yang akan dilakukan tindakan. Subjek adalah siswa kelas VIII 1 SMPN 1 Darussalam Aceh Besar sebanyak 32 siswa. Subjek dipilih atas dasar pertimbangan hasil belajar matematika yang masih kurang optimal, kurang terlibat aktif dalam pembelajaran dibandingan dengan subjek kelas berbeda. Kegiatan penelitian tindakan kelas dalam bentuk siklus dideskripsikan berikut ini.

\section{Siklus I}

Pada siklus I, materi yang diajarkan yaitu mengenalkan bentuk aljabar melalui beberapa contoh, memahami penjumlahan dan mengurangan bentuk aljabar. Tahap-tahap yang dilakukan pada siklus I dipaparkan berikut ini. Diawali dengan tahap perencanaan. Pada tahap ini peneliti mempersiapkan beberapa hal, yaitu Rencana Pelaksanaan Pembelajaran (RPP1) dengan menggunakan strategi peer lesson dengan media kartu, Lembar Kerja Peserta Didik (LKPD1) tentang penjumlahan dan pengurangan bentuk aljabar, lembar observasi aktivitas siswa, lembar observasi aktivitas guru mengelola pembelajaran, dan lembar respon siswa. Pelaksanaan pembelajaran siklus I, dimulai dengan kegiatan pembelajaran dibagi kedalam tiga tahap, yaitu kegiatan awal, inti, dan akhir. Tahap-tahap tersebut sesuai dengan RPP 1 .

Guru memulai pembelajaran dengan mengucapkan salam kemudian dilanjutkan dengan mereview materi yang telah lalu dengan membuat soal singkat. Selanjutnya menyampaikan tujuan pembelajaran serta rencana capaian hasil belajar matematika sebagaimana diharapkan. Penyampaian manfaat materi yang akan dipelajari dengan memberikan contoh dalam kehidupan sehari-hari. Kemudian memberikan informasi tentang strategi peer lesson dengan media kartu dengan langkahlangkah pembelajaran dan dilanjutkan peserta didik menunjukkan sikap untuk kerjasama, disiplin, peduli sosial dalam kelompok.

Guru menyampaikan informasi singkat tentang materi dalam RPP, kemudian membagi siswa dalam kelompok secara berpasangan dengan menyebutkan pasangan setiap kelompok. Setelah itu membagikan bacaan tambahan serta LKPD kepada masing-masing siswa. Selanjutnya memberi penjelasan jika ada penulisan di bahan bacaan yang kurang paham dan mendorong siswa untuk bertanya tentang materi yang mereka baca sebelumnya. Guru memberikan bantuan secukupnya bagi kelompok yang mengajukan pertanyaan tentang hal-hal yang belum mereka pahami terkait masalah yang disajikan. Kemudian memotivasi siswa untuk mencari dan menuliskan informasi pada permasalahan yang ada pada LKPD, mengarahkan siswa untuk menjawab sesuai langkah-langkah pada LKPD. Siswa membaca kembali bacaan tambahan yang telah diberikan guru agar permasalahan 
yang ada pada lembar kerja tersebut. Selanjutnya guru berkeliling dan membimbing siswa dalam mengerjakan dan mendiskusikan permasalahan yang ada pada LKPD.

Selanjutnya mengarahkan siswa untuk menuliskan ringkasan atau kesimpulan dari penyelesaian LKPD dan bacaan tambahan secara individu. Guru bersama siswa menetapkan siapa yang pertama menjadi pembicara dan pendengar. Guru memilih 5 (lima) pasangan dari 16 (enam belas) pasangan yang dibentuk untuk membaca hasil kesimpulan kepada pasangannya sesuai dengan peran yang diperoleh. Dari 5 (lima) pasangan yang telah dipilih, guru meminta satu persatu pasangan membacakan hasil kesimpulan dan siswa yang memperoleh peran sebagai pembicara membaca hasil kesimpulannya dan menjelaskan hasilnya kepada pasangan yang berperan sebagai pendengar untuk menyimak dan mengoreksi ringkasan yang kurang lengkap. Setelah itu guru meminta siswa untuk bertukar peran. Satu kelompok mempresentasikan hasil kegiatan didepan kelas. Namun pada kegiatan ini guru tidak menganjurkan setiap pasangan untuk membacakan hasil ringkasannya kepada pasangan masing-masing dikursi secara individu sehingga diskusi hanya dari beberapa kelompok saja.

Setelah diskusi dari beberapa kelompok yang telah dipilih guru memberikan penguatan tentang hasil diskusi yaitu tentang materi penjumlahan dan mengurangan bentuk aljabar dan penyelesaian permasalahan yang ada pada LKPD. Pada akhir proses pembelajaran guru merefleksi kegiatan yang telah dilakukan. Guru membimbing siswa untuk menyimpulkan materi pelajaran yang telah dibahas di kesimpulan akhir. Guru menutup pelajaran dengan salam. Adapun tes siklus I diberikan pada pertemuan selanjutnya. Berdasarkan observasi aktivitas guru yang diperoleh, guru dalam mengelola pembelajaran belum efektif, karena guru belum mampu mengontrol semua kelompok dengan baik. Ini akan menjadi bahan perbaikan pada pertemuan selanjutnya.

Kegiatan pengamatan siklus I terhadap aktivitas siswa juga dilakukan pada saat pembelajaran berlangsung. Pada awal proses pembelajaran siswa memulai dengan membaca asmaul-husna, kemudian mengingat materi prasyarat dengan menjawab beberapa pertanyaan yang diajukan guru. Siswa mendengar tujuan pembelajaran yang disampaikan oleh guru serta kebermanfaatan materi yang akan dipelajari. Siswa menyimak tentang strategi yang diterapkan dalam belajar yaitu strategi peer lesson dengan media kartu pada kegiatan yang dilakukan dalam kelompok nantinya. Pada kegiatan inti siswa mendengar informasi singkat dari guru mengenai materi materi penjumlahan dan mengurangan bentuk aljabar. Pada saat guru membagikan pasangan siswa bergerak mencari pasangannya. Kemudian membaca bahan bacaan tambahan dan mencermati permasalahan yang ada pada LKPD. Tidak banyak dari siswa yang menanyakan hal-hal yang kurang mereka pahami tentang materi dan permasalahan yang ada pada LKPD. Dari 32 siswa yang mengikuti pembelajaran hanya ada 4 atau 12,5\% siswa yang aktif bertanya tentang permasalahan yang ada, sedangkan siswa yang lain terlalu fokus membaca dan mengamati LKPD, sehingga belum ada yang menanggapi pertanyaan dari siswa yang mengajukan pertanyaan. Setelah mencermati permasalahan yang ada pada LKPD, siswa menuliskan jawaban sesuai dengan langkah-langkah yang tersedia. Jika ada siswa belum mendapatkan jawabannya, maka siswa membaca kembali bacaan tambahan untuk dapat mengatasi permasalahan pada LKPD. Kemudian siswa mendiskusikan masalah tersebut dengan pasangannya dengan bimbingan guru.

Setelah masalah yang ada pada LKPD diselesaikan, kemudian siswa membuat ringkasan atau kesimpulan secara individu. Setelah itu siswa mendapatkan peran pertama sebagai pembicara dan sebagai pendengar. Dari 16 (enam belas) pasangan, ada 5 (lima) pasangan dipilih untuk mempresentasikan hasil ringkasannya secara satu persatu kepada pasangannya dan siswa lain. Siswa yang berperan sebagai pembicara membaca hasil ringkasannya dan siswa yang berperan sebagai pendengar menyimak dan mengoreksi ringkasan yang kurang lengkap. Namun ada seorang siswa yang belum berani membaca atau kurang percaya diri untuk membaca hasil ringkasannya. Kemudian siswa bertukar peran yang semula sebagai pembicara ditukar menjadi pendengar dan sebaliknya. Pada kegiatan ini setiap pasangan tidak membacakan hasil ringkasannya kepada pasangan masing-masing 
secara individu sehingga hanya beberapa pasangan saja yang melakukan diskusi untuk semua. Setelah diskusi selesai siswa mendengar penguatan tentang hasil diskusi dan jawaban tentang permasalahan yang ada pada LKPD.

Pada kegiatan akhir siswa bersama-sama dengan guru merefleksi kembali materi yang telah dipelajari, kemudian siswa menuliskan kesimpulan akhir yang telah dibimbing oleh guru. Kemudian proses pembelajaran ditutup dengan ucapan salam dari guru dan siswa menjawab salam guru. Berdasarkan nilai hasil tes belajar siklus I, didapat 8 siswa yang belum mencapai ketuntasan belajar secara individu yaitu siswa yang memperoleh daya serap $<75$ sesuai dengan KKM. Adapun siswa yang memperoleh daya serap $\geq 75$ berjumlah 24 siswa. Dari persentase ketuntasan belajar secara klasikal sebesar 75\%. Sesuai dengan kriteria ketuntasan belajar secara klasikal dinyatakan tuntas apabila $85 \%$ siswa tuntas secara klasikal.

\section{Siklus II}

Sebelum melaksanakan siklus II, materi yang diajarkan melanjutkan pada siklus sebelumnya yaitu perkalian dan pembagian bentuk aljabar. Peneliti terlebih dahulu mempersiapkan beberapa perangkat yaitu: RPP II, LKPD II, soal siklus II, lembar observasi aktivitas siswa, lembar observasi aktivitas guru dalam mengelola pembelajaran. Kegiatan pembelajaran dimulai guru mengumumkan perolehan nilai pada kuis sebelumnya, bagi siswa yang nilainya sudah tinggi diharapkan agar dapat mempertahankannya. Bagi siswa yang nilainya masih rendah guru menyemangati agar tidak mudah menyerah dalam berusaha kemudian siswa diingatkan kembali materi sebelumnya. Kegiatan awal pembelajaran pada siklus II sama seperti pada siklus I, sebelum masuk ke dalam kegiatan inti guru mengingat kembali siswa tentang materi sebelumnya dan memberikan appersepsi dan memotivasi kebermanfaatan materi yang dipelajari.

Kegiatan selanjutnya yaitu tahap inti. Pada tahap ini, siswa memperhatikan informasi mengenai materi yang dipelajari kemudian mereka duduk secara berpasangan pada kelompok yang telah dibagikan. Setelah itu, guru membagikan LKPD kemudian meminta siswa mendiskusikan dan menyelesaikan masalah secara berpasangan dalam kelompoknya. Selama proses diskusi berlangsung, guru membimbing siswa dengan mengajukan pertanyaan-pertanyaan yang mengarah agar mereka bisa menyelesaikan permasalahan. Kegiatan dilanjutkan dengan membuat ringkasan dari penyelesaian LKPD secara individu. Kemudian dilanjutkan dengan menetapkan siapa yang berperan sebagai pembicara dan pendengar. Beberapa kelompok yang dipilih sebanyak 5 (lima) pasangan dari 16 (enam belas) pasanngan dengan diberikan tugas membaca hasil ringkasannya kepada pasangan masingmasing. Siswa yang berperan sebagai pembicara membaca hasil ringkasannya kepada siswa yang berperan sebagai pendengar, kemudian siswa bertukar peran dan guru memberikan penguatan hasil diskusi. Kegiatan pada tahap penutup, guru merefleksi kegiatan yang telah dilakukan setelah guru membimbing siswa dalam membuat kesimpulan tentang materi yang telah dipelajari.

Kegiatan pengamatan aktivitas guru pada siklus II dilakukan saat pembelajaran berlangsung. Guru memulai pembelajaran dengan mengucapkan salam kemudian dilanjutkan dengan mereview materi aturan perkalian dan pembagian bentuk aljabar. Kegiatan guru pada siklus II sama dengan pada siklus I, akan tetapi pada siklus II guru sudah dapat mengelola pembelajaran dengan efektif. Guru dapat mengontrol semua kelompok dengan baik. Kegiatan pengamatan aktivitas siswa, pada awal proses pembelajaran siswa memulai dengan membaca asmaul-husna terlebih dahulu, kemudian siswa mengingat kembali materi prasyarat dengan menjawab beberapa pertanyaan yang diajukan guru. Kegiatan selanjutnya yang dilakukan siswa seperti pada kegiatan di siklus I. Namun pada siklus II siswa sudah mulai antusias dalam menanyakan hal-hal yang kurang mereka pahami tentang materi dan permasalahan yang ada pada LKPD. Ada 8 atau 25\% dari siswa yang sudah aktif menanyakan tentang hal-hal yang kurang mereka pahami dan tentang permasalahan di LKPD.

Berdasarkan hasil tes evaluasi siklus I dan II bahwa hasil belajar siswa telah mencapai indikator keberhasilan dalam penelitian. Hal ini dapat dilihat dari meningkatnya nilai rata-rata siswa dari 
persentase ketuntasan hasil belajar siswa meningkat dari 75\% pada siklus I menjadi 87,5\% pada akhir siklus II. Data hasil belajar siswa disajikan pada Tabel 2 berikut ini.

Tabel 2 Perbandingan Capaian Ketuntasan Belajar Antar Siklus

\begin{tabular}{clccc}
\hline No & Aspek yang Diamati & Siklus I & \multicolumn{1}{c}{ Siklus II } & Rerata Tes Akhir \\
\hline 1 & Tuntas & 24 siswa & 28 siswa & 30 siswa \\
\hline 2 & Tidak tuntas & 8 siswa & 4 siswa & 2 siswa \\
\hline 3 & Persentasi Ketuntasan & $75 \%$ & $87,5 \%$ & $93,75 \%$ \\
\hline
\end{tabular}

Dari Tabel 2 menunjukkan bahwa peningkatan hasil belajar matematika siswa dapat dicermati dari hasil tes evaluasi siklus I dan siklus II dan tes akhir. Persentase hasil belajar siswa meningkat siklus I yaitu $75 \%$ menjadi $87,5 \%$ pada siklus II dan $93,75 \%$ pada tes akhir. Jumlah siswa yang mencapai KKM mengalami peningkatan dari 24 siswa pada siklus I menjadi 28 siswa pada siklus II dan 30 siswa pada tes akhir. Berdasarkan hasil penelitian yang dipaparkan sebelumnya, maka ada 3 (tiga) hal penting yang dibahas lebih lanjut yaitu: 1) aktivitas guru dalam mengelola pembelajaran, 2) aktivitas belajar siswa, dan 3) hasil belajar matematika dipaparkan berikut ini.

\section{Aktivitas Guru dalam Mengelola Pembelajaran}

Berdasarkan hasil deskripsi mengelola pembelajaran matematika menggunakan strategi peer lesson dengan media kartu pada siklus I, aktivitas guru dalam mengelola pembelajaran belum efektif karena belum mampu menguasai kelas dengan baik. Hasil observasi menunjukkan bahwa masih terdapat beberapa permasalahan seperti volume suara guru masih kecil dalam memberi penjelasan dan pengelolaan pembelajaran dalam hal ini belum menguasai siswa dengan baik, sehingga mereka belum berani bertanya tentang permasalahan yang ada. Guru belum mampu mengontrol setiap kelompok sehingga lebih terfokus pada beberapa kelompok saja. Guru belum memberikan kesempatan kepada seluruh siswa untuk saling membacakan hasil ringkasannya kepada pasangan masing-masing. Selanjutnya pada siklus II, aktivitas guru dalam mengelola pembelajaran mulai mengalami peningkatan. Guru sudah mampu menguasai siswa, dapat melakukan pengontrolan semua kelompok dan sudah menyuruh siswa untuk membacakan hasil ringkasan kepada pasangan masing-masing, sehingga mereka sudah banyak yang bertanya dan mulai aktif dalam pembelajaran matematika di kelas.

Kondisi pembelajaran matematika yang demikian memberikan perubahan bagi guru dalam pengelolaannya, sehingga berdampak positif bagi keaktifan siswa dalam belajar matematika. Jika dicermati dari strategi peer lesson yang memberikan peluang besar bagi siswa untuk aktif belajar, dan guru lebih banyak bertindak memfasilitasi siswa belajar sehingga mereka mudah beraktivitas dalam kelompok pasangannya (Silberman, 2009). Hasil deskripsi terhadap kemampuan guru diperoleh gambaran bahwa pembelajaran menggunakan strategi peer lesson dengan media kartu sudah efektif, karena sebagian besar siswa terlihat antusias dalam mengikuti proses pembelajaran dan seluruh kegiatan pembelajaran telah dilakukan dengan baik sesuai dengan yang telah direncanakan oleh guru. Menurut Slavin (1994) bahwa keefektifan belajar lebih menekankan pada kemampuan guru dalam mengelola pembelajaran serta kesesuaian waktu dalam menyelesaikan pelajaran dengan waktu yang direncanakan.

\section{Aktivitas Siswa Selama Pembelajaran}

Berdasarkan hasil deskripsi aktivitas siswa selama pembelajaran matematika menggunakan strategi peer lesson dengan media kartu diperoleh bahwa pada siklus I, aktivitas siswa selama pembelajaran matematika belum sepenuhnya aktif. Hal ini dikarenakan mereka merasakan pertama sekali kondisi pembelajaran yang menggunakan strategi seperti itu. Banyak siswa belum mampu mengikuti langkah-langkahnya dengan baik. Umumnya siswa belum berani bertanya tentang permasalahan yang ada dalam LKPD. Ada siswa sebanyak 4 orang atau $12,5 \%$ yang mau bertanya jawab dan masih ada yang merasa enggan dan tidak percaya diri ketika diminta untuk 
mempresentasikan hasil kerjanya. Selanjutnya pada siklus II, aktivitas siswa selama pembelajaran mulai mengalami peningkatan. Mereka mulai mengerti tentang strategi peer lesson dengan media kartu sehingga dapat mengikuti proses pembelajaran matematika dengan optimal. Siswa mulai bertanya pada siklus II tersebut, sehingga ada 8 (delapan) siswa yang sudah aktif bertanya dan tidak malu-malu lagi dalam membaca hasil kesimpulan yang telah mereka buat secara individu.

Berdasarkan kondisi keaktifan belajar siswa dalam proses pembelajaran matematika, maka potensi aktif siswa dalam belajar dengan menggunakan strategi peer lesson dapat menjadi optimal. Hal ini dapat dicermati dari langkah pembelajaran dengan menggunakan strategi peer lesson yang menekankan pada pelibatan siswa disetiap langkah pembelajarannya. Pelibatan siswa dalam pembelajaran akan menimbulkan kegairahan dan kemauan siswa untuk belajar dan mengajarkan materi kepada temannya (Zaini, 2008). Menurut Eggen dan Kauchak (1979) bahwa pembelajaran dikatakan aktif apabila siswa terlibat secara aktif dalam proses pembelajaran. Siswa tidak hanya pasif menerima informasi dari guru tetapi siswa sendiri yang berusaha untuk menemukan pengetahuan dengan sedikit arahan dari guru. Dari hasil penelitian penggunaan strategi peer lesson memberikan dampak positif bagi keaktifan siswa dalam belajarnya (Mulasiwi, Susilaningsih, \& Sumaryati, 2017; Relita, Marganingsih, \& Ningsih, 2017; Dwijayanti dan Pathoni, 2016).

\section{Hasil Belajar Siswa}

Pada pembelajaran siklus I, berdasarkan nilai hasil tes siklus I terdapat 8 (delapan) siswa yang belum mencapai ketuntasan belajar. Sehingga ketuntasan belajar siswa secara klasikal mencapai 75\% dari $85 \%$ yang diharapkan. Ketuntasan belajar siswa secara klasikal pada siklus I belum tercapai sebagaimana diharapkan. Peneliti melanjutkan perencanaan untuk melakukan tes pada siklus II, dengan harapan bahwa hasil tes siklus I yang belum mencapai ketuntasan secara klasikal tidak terulang kembali pada siklus II. Pada siklus II, guru memberi bantuan secukupnya bagi siswa yang belum tuntas pada tes siklus I dengan bimbingan. Hasil tes pada siklus II menunjukkan bahwa ketuntasan belajar siswa meningkat menjadi $87,5 \%$. Selanjutnya dilakukan tes akhir yang mencakup semua materi dari siklus I dan siklus II. Hasil tes akhir menunjukkan bahwa ketuntasan belajar siswa secara klasikal termasuk dalam kategori tuntas dengan persentase 93,75\% dengan Kriteria Ketuntasan Minimal (KKM) yaitu 75. Perubahan hasil belajar dari perolehan hasil tes siklus I, siklus II, dan tes akhir tersebut menunjukkan bahwa hasil belajar siswa meningkat dan optimal.

Peningkatan hasil belajar matematika siswa yang ditunjukkan dari data hasil tes tersebut menunjukkan bahwa strategi peer lesson memberikan dampak perubahan bagi siswa. Menurut Zaini (2008) perubahan bagi siswa terutama bekerja secara aktif dan meningkatkan kegairahan belajar mereka untuk memberikan penguatan materi kepada temannya. Hasil penelitian Dwijayanti dan Pathoni (2016) bahwa aktivitas siswa dan hasil belajarnya memberikan perubahan positif dan meningkat dengan menggunakan strategi peer lesson. Di lain penelitian menunjukkan penggunaan strategi peer lesson dapat meningkatkan kecerdasaan interpersonal siswa dalam belajar (Maharani, Kusmarni dan Kurniawati, 2018).

\section{KESIMPULAN}

Berdasarkan hasil dan pembahasan penelitian maka kesimpulan sebagai berikut: 1) strategi peer lesson dengan media kartu dapat meningkatkan aktivitas belajar siswa; 2) kemampuan guru dalam mengelola pembelajaran dalam kategori baik, dan 3) hasil belajar siswa meningkat dari siklus I ke siklus II dan tes akhir meningkat yaitu 93,75\%.

\section{REFERENCES}

Abdurrahman, Mulyono. (2012). Anak Berkesulitan Belajar. Jakarta: Rineka Cipta. 
Arikunto, Suharsimi., Suhardjono, \& Supardi. (2009). Penelitian Tindakan Kelas. Jakarta: Bina Aksara.

Dwijayanti, Esti dan Pathoni, Haerul. (2016). Penerapan Strategu Pembelajaran Aktif Peer Lesson untuk Meningkatkan Aktivitas dan Hasil Belajar Siswa pada Materi Suhu dan Kalor Kelas XA di SMAN 8 Kota Jambi. Jurnal EduFisika, (1)1, 18-21. Retrieved from http://doi.org/10.22437/edufisika.v1i1.2959.

Eggen, P.D., \& Kaucak. (1979). Strategies for Teachers Teaching Content and Thinking Skill. New Jersey: Prentice Hall.

Gagne, Robert. (1983). The Condition of Learning. Japan: Holt Saunders.

Maharani, Citra., Kusmarni, Yani dan Kurniawati S, Yeni. (2018). Penggunaan Strategi Pembelajaran Peer Lesson untuk Meningkatkan Kecerdasan Interpersonal Siswa dalam Pembelajaran Sejarah. Factum: Jurnal Sejarah dan Pendidikan Sejarah, (7)1, 43-52. Retrieved from http://ejournal.upi.edu/index.php/factum/article/view/11926.

Mulasiwi, Cut Misni., Susilaningsih \& Sumaryati, Sri. (2013). Upaya meningkatkan keaktifan dan hasil belajar akuntansi melalui strategi peer lessons dengan media ular tangga, jupe uns, 1(1), 1-14. Retrieved from https://eprints.uns.ac.id/1629/1/2128-4798-1-sm.pdf

Nuralam dan Gadeng, Tarmizi. (2018). Kualitas Hasil Belajar Statistika Siswa MTs yang Dibelajarkan dengan Pendekatan Problem Posing. Suska Journal of Mathematics Education. (4)2, 88-99. Retrieved from http://ejournal.uin-suska.ac.id/index.php/SJME/article/view/5744

Relita, Triana Dessy., Marganingsih, Anna., \& Ningsih, Utari Ulmi Hayati. (2017). Penerapan strategi pembelajaran akt tipe peer lessons terhadap kemampuan berpikir kritis siswa. Sosio didaktika: social science education journal, 4 (2), 1-12. Retrieved from http://journal.uinjkt.ac.id/index.php/sosio-fitk

Ruseffendi, E.T. (2005). Dasar-Dasar Matematika Modern dan Komputer untuk Guru. Bandung: Tarsito.

Sanjaya, Wina. (2007). Strategi Pembelajaran Berorientasi Standar Proses Pendidikan. Jakarta: Kencana.

Sari, Dewi Puspita dan Faisal. (2018). Identifikasi upaya guru menyediakan media pembelajaran matematika di SMA Negeri 1 Manyak Payed. Jurnal Ilmiah Pendidikan Matematika AlQalasadi, (2)2, 57-64. Retrieved from http://journal.iainlangsa.ac.id/index.php/qalasadi/article/view/799

Silberman, Melvin L. (2009). Active Learning 101 Cara BelajarAktif. Jakarta: Pustaka Insani Madani

Slavin, Robert. (1994). Educational Psychology: Theories and Practice. Fourth Edition. Massachusetts: Allyn and Bacon Publishers.

Sudjana, Nana (2011). Penilaian Hasil Proses Belajar Mengajar. Bandung: Remaja Rosda Karya.

Suherman, Erman, dkk. (2001). Strategi Pembelajaran Matematika Kontemporer. Bandung: Universitas Pendidikan Indonesia.

Sunarto dan Hartono, B. Agung. (2006). Perkembangan Peserta Didik. Jakarta: PT Rineka Cipta.

Susilo, Frans. (2012). Landasan Matematika. Yogyakarta: Graha Ilmu. 
Zaini, Hisyam. (2008). Strategi Pembelajaran Aktif. Yogyakarta: CTSD UIN Sunan Kalijaga. 